\title{
VALIDITAS MODUL MATEMATIKA KELAS X SMA DENGAN MENERAPKAN VARIASI MODEL PEMBELAJARAN KOOPERATIF
}

\author{
Tetty Natalia Sipayung ${ }^{1}$, Sinta Dameria Simanjuntak ${ }^{2}$ \\ ${ }^{1,2}$ Universitas Katolik Santo Thomas \\ 1tettysipayung83@gmail.com,_2sh1_nta@yahoo.com
}

\begin{abstract}
This research which is entitled as a grade X of Senior High School by applying variations of cooperative learning model on each presented material. The research method used is a research development method which is used to produce a developed module and to test the effectiveness. The validity of module in this research is based on the feasibility of the standard of the media and material. The media feasibility standard of the module consists of aspects of both in graphs and language. The module eligibility standart includes the feasibility aspects of the contents, presentation and contextual assessment. The average score for the aspect of feasibility in graph value is 3.95, the language value is 3.93, the content value aspect is 3.99, and the aspect of valuation of contextual is 4. Thus, the mathematics module for grade X of Senior High School which is developed in this research is valid.
\end{abstract}

Keywords: validity, development of mathematics module, cooperative learning

\begin{abstract}
Abstrak. Penelitian dengan judul validitas modul matematika kelas X SMA dengan menerapkan variasi model pembelajaran kooperatif ini bertujuan untuk mengembangkan modul matematika kelas X SMA dengan menggunakan variasi-variasi model pembelajaran kooperatif pada setiap materi yang disajikan. Metode penelitian yang digunakan adalah metode penelitian pengembangan yaitu metode penelitian yang digunakan untuk menghasilkan produk tertentu dan menguji keefektifannya. Produk yang dikembangkan adalah modul matematika kelas SMA. Validitas modul dalam penelitian ini ditinjau berdasarkan standart kelayakan media modul dan standart kelayakan materi modul. Standart kelayakan media modul terdiri dari aspek kelayakan kegrafikan dan aspek kelayakan bahasa. Standart kelayakan materi modul mencakup aspek kelayakan isi, aspek kelayakan penyajian dan aspek penilaian kontekstual. Skor rata-rata hasil validitas aspek kelayakan kegrafikan bernilai 3,95, aspek kelayakan bahasa bernilai 3,97, aspek kelayakan isi bernilai 3,93, aspek kelayakan penyajian bernilai 3,99, dan aspek penilaian kontekstual bernilai 4. Dengan demikian hasil yang diperoleh dari penelitian ini adalah modul matematika kelas X SMA yang dikembangkan valid.
\end{abstract}

Kata Kunci: validitas, pengembangan modul matematika, pembelajaran kooperatif

\section{PENDAHULUAN}

Tidak dapat dipungkiri bahwa pembelajaran matematika yang sedang berlangsung di sekolah-sekolah masih cenderung menggunakan sumber belajar dan media belajar yang seadanya. Sumber belajar yang digunakan masih terdiri dari buku yang disediakan pemerintah ataupun buku yang disarankan guru untuk dipakai oleh siswa yang diperoleh melalui penerbit buku tertentu. Sedangkan media belajar yang digunakan cenderung tidak ada. Hal tersebut membuat cakupan dan wawasan pembelajaran menjadi sempit dan terbatas.

Jika ditinjau dari filosofi kurikulum 2013, pembelajaran seharusnya berangkat dari konteks yang dekat pada diri siswa. Pembelajaran yang berangkat melalui konteks diri siswa diharapkan akan membangun pemahaman yang bermakna dan ingatan yang lama. Dengan demikian, diperlukan sumber belajar dan media belajar yang berbeda 
untuk siswa yang berada pada lingkungan yang berbeda. Yang paham dengan lingkungan kontekstual siswa adalah guru. Untuk itu, guru seharusnya tidak hanya memanfaatkan sumber belajar dan media belajar yang disediakan pemerintah ataupun penerbit. Buku yang disediakan pemerintah dan penerbit tentunya pasti akan bersifat umum dan nasional supaya dapat digunakan secara nasional. Namun, yang dibutuhkan siswa pada saat ini adalah yang khusus, yang detail, yang nyata dan yang ada dekat pada konteks lingkungannya.

Untuk menjangkau kebutuhan tersebut, diperlukan sumber dan media belajar selain buku yang disediakan pemerintah ataupun penerbit. Salah satu sumber dan media belajar yang dimaksud adalah modul. Modul adalah sumber dan media belajar yang dikembangkan sendiri sesuai dengan kebutuhan. Di dalam sebuah modul minimal memuat tujuan dan proses pembelajaran, uraian materi, tes, rangkuman dan kunci jawaban. Dengan modul yang dirancang sendiri sesuai kebutuhan dan isi standar minimal modul diharapkan akan meningkatkan pemahaman, pemecahan masalah, hasil belajar dan keaktifan siswa.

Manfaat pengembangan modul yang telah diungkapkan tersebut sejalan dengan beberapa penelitian relevan yang pernah dilaksanakan sebelumnya. Beberapa pnelitian tersebut diantaranya adalah penelitian yang dilakukan oleh Harahap (2013) dengan hasil penelitian yang menyatakan bahwa pembelajaran Hak Asasi Manusia dengan menggunakan modul adalah efektif. Penelitian selanjutnya adalah penelitian yang dilakukan oleh Santyasa, dkk (1999) dengan hasil penelitian yang menyatakan bahwa penerapan modul dapat mengubah miskonsepsi siswa menjadi konsepsi ilmiah dan dapat meningkatkan hasil belajar.

Berdasarkan uraian yang telah dipaparkan, konteks penelitian ini adalah pengembangan modul matematika. Pengembangan modul yang dilakukan dalam penelitian ini adalah pada materi semester ganjil kelas X SMA. Tujuan dari penelitian ini adalah menghasilkan modul yang valid untuk dapat digunakan dalam pembelajaran matematika kelas X SMA dengan menerapkan variasi-variasi model pembelajaran koopertaif sehingga siswa memiliki sumber dan media belajar yang lebih komunikatif dan dekat dengan konteks lingkungan dirinya sendiri. Dengan demikian matematika dapat menjadi suatu pelajaran yang disenangi dan disukai siswa.

\section{METODE}

Jenis penelitian ini adalah penelitian pengembangan. Yang dikembangkan dalam penelitian ini adalah sumber dan media belajar berupa modul. Modul yang dikembangkan adalah modul matematika kelas X SMA matematika pada semester ganjil yang disesuaikan dengan kurikulum 2013 dengan menerapkan pembelajaran kooperatif yang bervariasi pada setiap materi yang disajikan. Penelitian ini dilaksanakan di SMA Nusantara Lubuk Pakam Jln. Teuku Raja Muda No.1 Lubuk Pakam. Subjek dari penelitian ini adalah siswa kelas XMIA-1 SMA Nusantara Lubuk Pakam Tahun Ajaran 2017/2018. Objek penelitian ini adalah modul matematika kelas X SMA dengan penerapan variasi model pembelajaran kooperatif pada setiap materi.

Untuk menghasilkan produk pembelajaran interaktif diperlukan perencanaan perancangan pembelajaran yang baik pula. Pengembangan bahan ajar interaktif ini digunakan rancangan pengembangan model Dick and Carey (Trianto, 2009:187-190) dimana pengembangan pembelajaran dilakukan dengan tahap-tahap sebagai berikut: 
1. Identifikasi Tujuan Pengajaran

Tahap awal model ini adalah menentukan apa yang diinginkan agar siswa dapat melakukannya ketika mereka telah menyelesaikan program pengajarannya. Definisi tujuan pengajaran mungkin mengacu pada kurikulum tertentu atau mungkin juga berasal dari daftar tujuan sebagai hasil need assesment, atau dari pengalaman praktik dengan kesulitan belajar siswa di dalam kelas.

2. Melakukan Analisis Instruksional

Setelah mengidentifikasi tujuan pembelajaran, maka akan ditentukan apa tipe belajar yang dibutuhkan siswa. Tujuan yang dianalisis untuk mengidentifikasi keterampilan yang lebih khusus lagi yang harus dipelajari. Analisis ini akan menghasilkan chart atau diagram tentang keterampilan-keterampilan/konsep dan menunjukkan keterkaitan antara keterampilan/konsep tersebut.

3. Mengidentifikasi Tingkah Laku Awal/Karakteristik Siswa

Ketika melakukan analisis terhadap keterampilan-keterampilan yang perlu dilatihkan dan tahapan prosedur yang perlu dilewati, juga harus dipertimbangkan keterampilan apa yang dimiliki siswa saat mulai mengikuti pengajaran. Yang penting mengikuti penting juga untuk diidentifikasi adalah karakteristik khusus siswa yang mungkin ada hubungannya dengan rancangan aktivitas-aktivitas pengajaran.

4. Merumuskan Tujuan Kinerja

Berdasarkan analisis instruksional dan pernyataan tentang tingkah laku siswa, selanjutnya akan dirumuskan pernyataan khusus tentang apa yang harus dilakukan siswa setelah menyelesaikan pembelajaran.

5. Pengembangan Tes Acuan Patokan

Berdasarkan pada tujuan yang telah dirumuskan, maka dilakukan pengembangan butir assesment untuk mengukur kemampuan siswa seperti yang diperkirakan di dalam tujuan.

Pengembangan Strategi Pengajaran

6. Informasi dari lima tahap sebelumnya, maka selanjutnya akan mengidentifikasi yang akan digunakan untuk mencapai tujuan akhir. Strategi akan meliputi aktivitas preinstruksional, penyampaian informasi, praktik dan balikan, testing yang dilakukan lewat aktivitas.

7. Pengembangan atau Memilih Pengajaran.

Tahap ini akan digunakan strategi pengajaran untuk menghasilkan pengajaran yang meliputi petunjuk untuk siswa, bahan pelajaran, tes, dan panduan guru.

8. Merancang dan Melaksanakan Evaluasi Formatif.

Evaluasi dilakukan untuk mengumpulkan data yang digunakan untuk mengiddentifikasi bagaimana meningkatkan pengajaran.

9. Menulis Perangkat.

Hasil-hasil pada tahap di atas dijadikan dasar untuk menulis perangkat yang dibutuhkan. Hasil perangkat selanjutnya divalidasi dan diujicobakan di kelas/diimplementasikan di kelas.

10. Revisi Pengajaran

Tahap ini mengulangi siklus pengembangan perangkat pengajaran. Data dari evaluasi sumatif yang telah dilakukan pada tahap sebelumnya diringkas dan dianalisi serta dinterpretasikan untuk diidentifikasi kesulitan yang dialami oleh siswa dalam mencapai tujuan pembelajaran. Begitu pula masukan dari hasil implementasi dan pakar/validator. 
Tetty Natalia Sipayung, Sinta Dameria Simanjuntak Validitas Modul Matematika Kelas X SMA dengan Menerapkan Variasi Model....

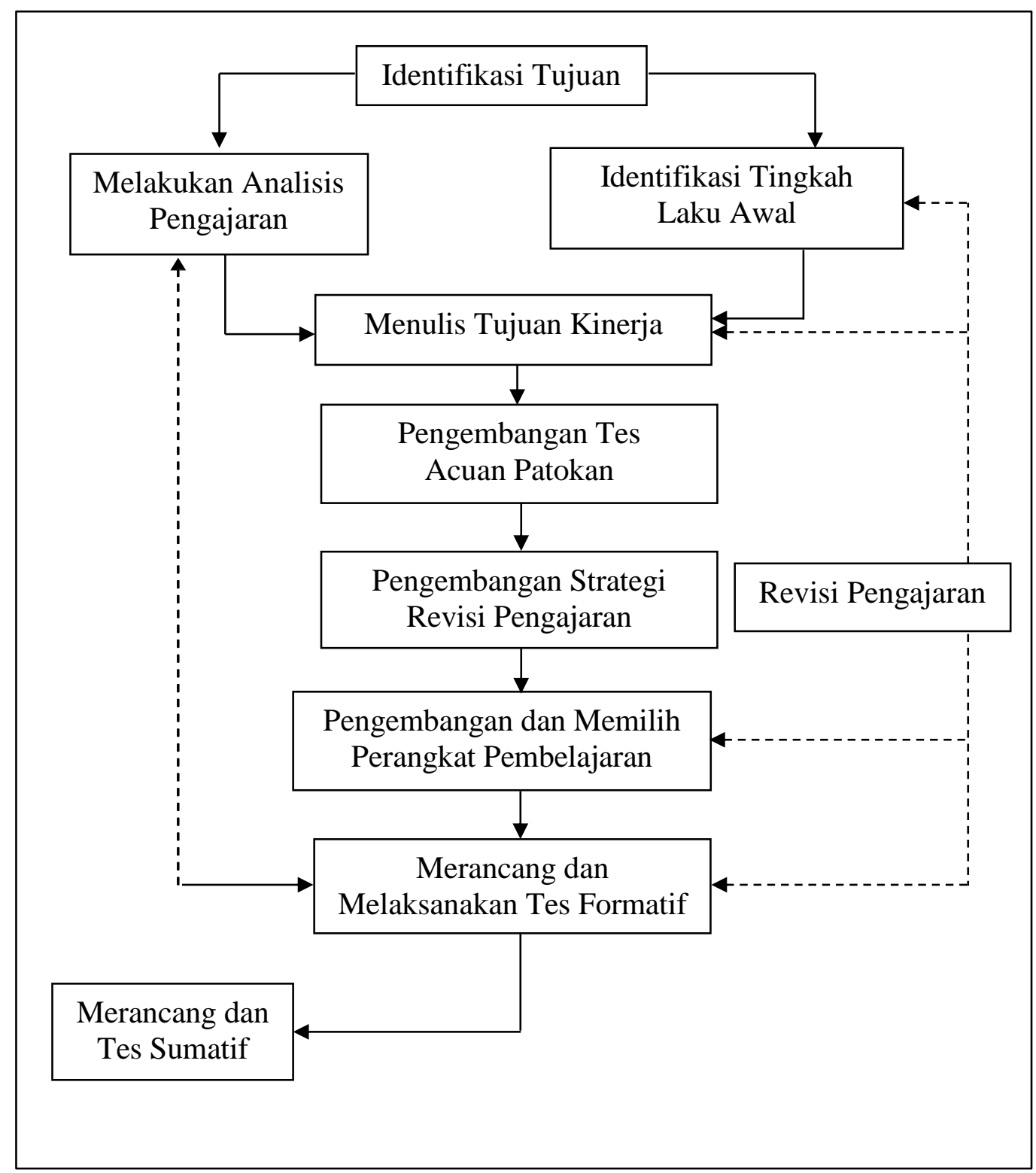

Gambar 1. Model Perancangan dan Pengembangan Pengajaran Menurut Dick \& Carey

Sumber data dari penelitian ini adalah sumber data yang diperoleh dari hasil validasi validator yang dianggap ahli dalam materi matematika. Validator yang dimaksud terdiri dari satu orang guru matematika dan satu orang dosen pendidikan matematika. Pengumpulan data dalam penelitian ini dilakukan melalui teknik non tes. Non tes yang digunakan adalah lembar validasi untuk modul yang terdiri dari aspek kelayakan kegrafikan, kelayakan bahasa, aspek kelayakan isi, aspek kelayakan penyajian dan aspek penilaian kontekstual. Instrumen yang digunakan dalam penelitian ini adalah instrumen validasi modul. Validitas modul dalam penelitian ini ditinjau berdasarkan standart kelayakan media modul dan standart kelayakan materi modul. Standart kelayakan media modul terdiri dari aspek kelayakan kegrafikan dan aspek kelayakan bahasa. Standart kelayakan materi modul mencakup aspek kelayakan isi, aspek kelayakan penyajian dan aspek penilaian kontekstual. Teknik analisis data yang digunakan dalam penelitian ini adalah analisis deskriptif kualitatif. Teknik analisis 
deskriptif yang dimaksud adalah validasi sumber dan media ajar modul matematika kelas X SMA. Validasi sumber dan bahan bahan ajar modul dilakukan oleh ahli materi matematika yaitu dosen pendidikan matematika dan guru bidang studi matematika melalui lembar validasi yang telah disediakan.

\section{HASIL DAN PEMBAHASAN \\ Hasil}

Penilaian modul dilakukan oleh dua orang validator dalam bidang pendidikan matematika. Validator tersebut adalah satu orang dosen pendidikan matematika dan satu orang guru matematika SMA. Dengan demikian hasil yang diperoleh dari penelitian ini adalah modul matematika kelas X SMA yang dikembangkan valid. Hal tersebut dapat dilihat pada tabel berikut:

Tabel 1. Standart Kelayakan Media Modul

\begin{tabular}{cccc}
\hline No. & \multicolumn{1}{c}{ Aspek } & Skor Rata-Rata & Kriteria Validasi \\
\hline 1. & Kelayakan Kegrafikan & 3,95 & Valid dan tidak perlu direvisi \\
\hline 2. & Kelayakan Bahasa & 3,97 & Valid dan tidak perlu direvisi \\
\hline
\end{tabular}

Tabel 2. Standart Kelayakan Materi Modul

\begin{tabular}{cccc}
\hline No. & \multicolumn{1}{c}{ Aspek } & Skor Rata-Rata & Kriteria Validasi \\
\hline 1. & Kelayakan Isi & 3,93 & Valid dan tidak perlu direvisi \\
\hline 2. & Kelayakan Penyajian & 3,99 & Valid dan tidak perlu direvisi \\
\hline 3. & Penilaian Kontekstual & 4 & Valid dan tidak perlu direvisi \\
\hline
\end{tabular}

Dengan demikian hasil penelitian yang diperoleh dapat dirangkum sebagai berikut: skor rata-rata hasil validitas aspek kelayakan kegrafikan bernilai 3,95, aspek kelayakan bahasa bernilai 3,97, aspek kelayakan isi bernilai 3,93, aspek kelayakan penyajian bernilai 3,99, dan aspek penilaian kontekstual bernilai 4 .

\section{Pembahasan}

Modul dalam penelitian ini dinilai berdasarkan dua standart yaitu standart kelayakan media modul dan standart kelayakan materi. Standart kelayakan media modul terdiri dari dua aspek yaitu aspek kelayakan kegrafikan dan aspek kelayakan bahasa. Standart kelayakan materi terdiri dari 3 aspek yaitu aspek kelayakan isi, aspek kelayakan penyajian dan aspek penilaian kontekstual. Indikator aspek kelayakan kegrafikan terdiri dari ukuran modul, keakuratan materi dan disain isi modul. Indikator kelayakan bahasa terdiri dari lugas, komunikatif, dialogis dan interatif, kesesuaian dengan perkembangan peserta didik, kesesuaian dengan kaidah bahasa dan penggunaan istilah/simbol/ikon. Indikator dari aspek kelayakan isi adalah kesesuaian materi dengan standart kompetensi dan kompetensi dasar, keakuratan materi, kemutakhiran materi dan mendorong keingintahuan. Indikator dari aspek kelayakan penyajian adalah teknik penyajian, pendukung penyajian, penyajian pembelajaran, koherensi dan keruntutan alur pikir. Indikator dari aspek penilaian kontekstual adalah memuat hakikat kontekstual dan komponen kontekstual.

Hasil penilaian modul yang diperoleh dari dua validator tersebut berdasarkan standart kelayakan media modul akan diuraikan sebaga berikut. Penilaian untuk ukuran modul memperoleh skor rata-rata 4, penilaian untuk keakuratan materi memperoleh skor rata-rata 3,88 dan penilaian untuk desain isi modul memperoleh 
skor rata-rat 3,97. Sehingga skor rata-rata untuk aspek kelayakan kegrafikan adalah 3,95. Penilaian untuk kelugasan bahasa modul memperoleh skor rata-rata 4 , komunikatif modul memperoleh skor rata-rata 4, dialogis dan interaktif modul memperoleh skor rata-rata 4, kesesuaian dengan perkembangan peserta didik memperoleh skor rata-rata 4, kesesuaian dengan kaidah bahasa memperoleh skor ratarata 4 dan penggunaan istilah/simbol/ikon memperoleh skor rata-rata 4 . Sehingga skor rata-rata untuk aspek kelayakan bahasa adalah 3,97.

Hasil penilaian modul berdasarkan standart kelayakan materi yang dinilai berdasarkan 3 aspek diuraikan sebagai berikut. Penilaian untuk adalah kesesuaian materi dengan standart kompetensi dan kompetensi dasar memperoleh skor rata-rata 4, penilaian untuk keakuratan materi memperoleh skor rata-rata 4, penilaian kemutakhiran materi memperoleh skor rata-rata 3,7 dan penilaian untuk mendorong keingintahuan memperoleh skor rata-rata 4. Sehingga skor rata-rata untuk aspek kelayakan isi adalah 3,93. Penilaian untuk teknik penyajian memperoleh skor ratarata 4, penilaian untuk pendukung penyajian memperoleh skor rata-rata 3,94, penilaian untuk penyajian pembelajaran memperoleh skor rata-rata 4 serta. Penilaian untuk koherensi dan keruntutan alur pikir memperoleh skor rata-rata 4. Sehingga skor rata-rata untuk aspek kelayakan penyajian adalah 3,99. Penilaian untuk hakikat kontekstual memperoleh skor rata-rata 4 dan penilaian untuk komponen kontekstual memperoleh skor rata-rata 4. Sehingga skor rata-rata untuk aspek penilaian kontekstual adalah 4. Dengan demikian hasil yang diperoleh dari penelitian ini adalah modul matematika kelas X SMA yang dikembangkan valid.

\section{KESIMPULAN DAN SARAN}

Berdasarkan hasil penelitian yang telah dikemukakan, maka diperoleh kesimpulan bahwa modul matematika kelas X SMA yang dikembangkan dengan menerapkan variasi model pembelajaran kooperatif pada setiap materi adalah valid. Adapun saran dalam penelitian ini adalah modul dari hasil penelitian ini dapat dijadikan sebagai pertimbangan guru dalam mengembangkan modul pembelajaran sebagai upaya meningkatkan hasil belajar dan pemahaman siswa serta kemampuan dalam memecahkan masalah.

\section{UCAPAN TERIMAKASIH}

Penulis menyampaikan terimakasih kepada Kementerian Riset, Teknologi dan Pendidikan Tinggi (Kemristekdikti) Republik Indonesia atas dukungan dan bantuan dana penelitian dalam skema Penelitian Dosen Pemula Tahun Anggaran 2017 yang sudah diberikan sehingga penelitian ini bisa dilaksanakan dengan baik dan hasil penelitian dapat dipublikasikan melalui tulisan ini.

\section{DAFTAR PUSTAKA}

Hendriana, Heris, dkk. 2014. Penilaian Pembelajaran Matematika. Bandung: PT. Refika Aditama.

Purnomo, A.E., Fathurohman, A., Budiharto. 2014. Keefektifan Model Pembelajaran Ideal Problem Solving Berbasis Maple Mata Kuliah Kalkulus II. Jurnal JKP. 1(2). 7-17. ISSN: 2339-2444.

Rusiyanti, R. H. 2011. Pengembangan Perangkat Pembelajaran Matematika Berbasis Konstruktivisme untuk Melatih Kemampuan Berpikir Kritis Siswa Kelas X. Jurnal Pendidikan Matematika. 5(2).185-204. 
Vol. 3, No. 1, Oktober 2017

Trianto. 2009. Mendesain Model Pembelajaran Inovatif-Progresif, Konsep, Landasan, dan Implementasinya Pada Kurikulum Tingkat Satuan Pendidikan (KTSP). Jakarta: Kencana. 